\title{
AN INVESTIGATION INTO THE ECOTOURISM DEVELOPMENT POTENTIAL IN ILLUKKUMBURA AREA IN THE KNUCKLES RANGE
}

\author{
C. Maelge \& D.M.S. H. K. Ranasinghe \\ Department of Forestry and Envirobmental Science, \\ University of Sri Jayewardenepura
}

Knuckles National Heritage Wilderness Aiea is approximately $155 \mathrm{~km}^{2}$ and is located in the Central Province of Sri Lanka. Knuckies forested area has high endemic biodiversity and possesses a rich cultural history. It falls under the administration of the Forest Department. The area has been separated into three different zones, for systematic implementation of ecotourism activities. Illukkumbura is one such ecotourism zone of the Knuckles forested area.

Objectives of the study are to explore the ecotourism development potential of Illukkumbura area, promotion of local community participation in ecotourism and recommendation of strategies to promote lllukkumbura area in the global tourism market. Comprehensive litrature survey was conducted to gather secondary data, with regard to ecotourism and its subject matter. Primary data was collected initially through a reconnaissance survey, to demarcate the study site, familiarize with key decision makers of the villages and provided the basis to select the study area and participant for the Participatory Rural Appraisal as well as decide on the time duration of the Participatory Rural Appraisal. To gather in depth primary data Participatory Rural Appraisal was conducted in the selected villages, with a questionnaire assisted interview process. The respondents were selected using random sample techniques, which comprised of 50 participants. Field observations were carried out in all ecotourism attractions at Illukkumbura area. Specific attention was given to the site selection for suitable ecotourism activities, especially suited for various ecotourists.

Study revealed that Illukkumbura zone is patronized by tourist both domestic and foreign at present mainly for trekking, swimming and camping. Study resulted in evaluating the importance of the each nature trail for ecotourism, exploring other ecotourism sites in the area, exploring the potential of community participation in ecotourism, developing a communication strategy for the area and drawing up proposed guidelines for a ecotourism development plan in the Illukkumbura area. Recommendations were made in line to promote continuous research with relation to ecotourism and adapt better management ecotourism practices for sustainable development.

Proceedings of the Eighth Annual Forestry and Environment Symposium 2002 of the Department of Forestry and Environmental Science, Lniversity of Sri Jayewardenepura, Sri Lanka 